\title{
Changes in Beverage Intake Between 1977 and 2001
}

\author{
Samara Joy Nielsen, BS, Barry M. Popkin, PhD
}

Objective:

To examine American beverage consumption trends and causes.

Methods: Nationally representative data from the 1977-1978 Nationwide Food Consumption Survey, the 1989-1991 and 1994-1996 (also for children aged 2 to 9 years in 1998) Continuing Surveys of Food Intake by Individuals (CSFII), and 1999-2001 National Health and Nutrition Examination Survey were used in this study. The sample consisted of 73,345 individuals, aged $\geq 2$ years. For each survey year, the percentage of total energy intake from meals and snacks was calculated separately for respondents aged 2 to 18 years, 19 to 39, 40 to 59 , and $\geq 60$. The percentage of energy intake by location (at home consumption or preparation, vending, store eaten out, restaurant/fast food, and school), as well as for specific beverages was computed separately for all age groups. The proportion consumed, mean portion size, and number of servings were calculated.

Results: $\quad$ For all age groups, sweetened beverage consumption increased and milk consumption decreased. Overall, energy intake from sweetened beverages increased $135 \%$ and was reduced by $38 \%$ from milk, with a 278 total calorie increase. These trends were associated with increased proportions of Americans consuming larger portions, more servings per day of sweetened beverage, and reductions in these same measures for milk.

Conclusions: There is little research that has focused on the beneficial impacts of reduced soft drink and fruit drink intake. This would seem to be one of the simpler ways to reduce obesity in the United States.

(Am J Prev Med 2004;27(3):205-210) @ 2004 American Journal of Preventive Medicine

\section{Introduction}

I arge increases in Americans' caloric intake have occurred in the past decade to match longerterm shifts in eating patterns. ${ }^{1}$ Among increases of great concern have been the greater intake of sugar and other caloric sweeteners, the greater consumption of foods consumed away from the home, and the greater consumption of fast foods. ${ }^{2-12}$ Although many have examined the shifts in Americans' diets, few have looked specifically at the changes in beverage consumption. ${ }^{5-7,11}$ It is clear that there have been many dietary shifts, including more unhealthy fast foods. ${ }^{1,8,9}$ While many have focused on the increase in soft drinks, others have been equally concerned with the reduced milk consumption and reduced calcium intake of American children and adolescents. ${ }^{9,10}$

This paper analyzes changes in beverage consumption as a percentage of total energy between 1977 and 2001. There are two well-known co-evolving trends: a decrease in milk consumption and an accompanying increase in sweetened beverages. It is presently unclear

From the Department of Nutrition, University of North Carolina at Chapel Hill, Chapel Hill, North Carolina

Address correspondence to: Barry M. Popkin, Professor of Nutrition, Carolina Population Center, University of North Carolina at Chapel Hill, CB \# 8120 University Square, 123 W. Franklin Street, Chapel Hill NC 27516-3997. E-mail: popkin@unc.edu what is driving these changes. Meal or snack diets, or both, can change for home and away-from-home locations, such as vending, restaurant, and fast food locations. Furthermore, the per day shifts-represented by changes in the proportion of consumers of a product line, shifts in the portion sizes consumed, and even shifts in the number of eating occasions for the food group-can be seen. This paper goes beyond other beverage trend studies that focused on specific age groups, and did not examine the full range of possible changes, including number of servings and portion sizes. The analysis sample consisted of nationally representative Americans aged $\geq 2$ years, with subgroupings of children (2 to 18 years), young adults (19 to 39 years), middle-aged adults (40 to 59 years), and older adults ( $\geq 60$ years).

\section{Methods \\ Survey Design and Sample}

This study used data on subjects, aged $\geq 2$ years, from four nationally representative independent surveys of the U.S. population. Of 73,345 individuals, 29,695 participated in the 1977-1978 Nationwide Food Consumption Survey (NFCS77), 14,658 participated in the 1989-1991 Continuing Survey of Food Intake by Individuals (CSFII89), and 19,027 participated in the 1994-1996 Continuing Survey of Food Intake by Individuals (CSFII96). This survey also included a sample of 
children aged 2 to 9 years who were surveyed in 1998. A total of 9965 participated in the 1999-2001 National Health and Nutrition Examination Survey (NHANES 99-01). These surveys, which contained stratified area probability samples of non-institutionalized U.S. households in the 48 contiguous states and in all 50 states in 1996 and 1999-2001, were self-weighting, multistage, stratified area samples of the U.S. population. Detailed information pertaining to each survey has been published elsewhere. ${ }^{13-16}$

The NFCS77 and CSFII89 surveys collected 1 day of intake by in-home, interviewer-administered, 24-hour recall, and 2 additional days of self-administered 1-day food records. The CSFII96 collected two nonconsecutive, interviewer-administered 24-hour recalls by telephone approximately 10 days apart. The 1999-2001 survey collected 1 day of in-person, interviewer-administered, 24-hour recall. As a result, only the 1999-2001 survey results were used to examine the proportion of energy from the beverages and not the 2-day average of the percentage of consumers, number of servings, and portion sizes. Moreover, this last survey had different specifications for the location where food was consumed as well as the meal types, so it was not used to assess trends in the location of consumption.

For each food consumed in these surveys, the respondent was asked whether this eating occasion was a meal or snack, where the food was obtained, and if the food was bought in a store. It was then determined whether the food was eaten at home and whether the food was ever brought into the home. This led to the classification of food sources as either from a vending machine, eaten or prepared at home, from a store (but not eaten or ever brought into the home; called store eaten out), from a fast food establishment or restaurant (called restaurant/fast food), from a school (termed school), or as a gift from someone or any other miscellaneous source. Aside from food bought from a store, food prepared in any other source was considered to be from that source even if brought into the home. For example, if someone ordered pizza from a pizza restaurant or picked up fast food on the way home and ate it in their home, that food was still considered as belonging to the restaurant/fast food category.

To examine the thousands of foods contributing to energy intake, the University of North Carolina-Chapel Hill food grouping system was used. This system aggregates all foods in the U.S. Department of Agriculture's nutrient composition tables into 74 descriptive and nutrient-based subgroups. The only foods examined in this paper were beverages, including milk, fruit juices, soft drinks, fruit drinks, coffee and tea, and alcohol (including beer, wine, and liquor). The liquid milk category was a subset of milk and all milk products (no dairy foods included). The other milk beverage category was defined as beverages with too little milk (determined by the National Dairy Council) to be included in the milk category, but still contained at least $50 \%$ milk (e.g., fruit smoothies with dairy products, cocoa made with milk, and milk shakes).

\section{Statistical Analysis}

The dietary data contained each food item that a person consumed, the self-reported eating occasion, and the selfreported place where the food was obtained and eaten. After foods were categorized by eating occasion (snacks vs nonsnack meals), the mean energy (kilocalories) and percentage energy contributed by snacks and nonsnacks (meals) were computed for each survey year by age group. Then, for each survey year, the mean percentage of energy consumed in each beverage category was determined for the food and the location (at home, vending, store eaten out, restaurant/fast food, and school), and separately for each age group (i.e., 2 to 18 years, 19 to 39,40 to 59 , and $\geq 60$ ).

The mean portion sizes were calculated using self-reported portion sizes of beverages at one meal or snack. This was a per consumer mean-not a per capita mean-to show that the mean portion size for those who consumed a specific beverage had changed over time, not that the number of people consuming an item had changed. Both two-dimensional and three-dimensional food models were used to assist respondents in identifying the size of a portion. During phone interviews, these models were not used, but respondents were still queried about portion sizes. For the second day of data in 1994-1996, phone interviews were only conducted on individuals who had already completed an in-person interview using food models. However, due to data collection methods, there was enormous variability in portion size among individuals, based on the individual's specification of how much was consumed. These data reflected the beverage size consumed by an individual at a specific eating occasion. All analyses used the CSFII96 updated nutrient database.

Servings were calculated only using consumers to show that among people consuming these beverages, the number of servings changed during the day. Beverage items that had a beginning drinking time $>15$ minutes after the initial beverage were consumed as a discrete "serving." Portions were the number of kilocalories or grams consumed by an individual at one eating occasion, while servings were the number of discrete times someone consumed an item.

To test for statistical differences, SAS 8.1 (SAS Institute Inc., Cary NC, 1999-2001) and SUDAAN 7.5.6 (Research Triangle Park NC, July 2001) software packages were used, which also allowed for weights and control of sample design effects. A $p$ value of 0.01 was used to denote statistical significance.

\section{Results \\ Overall Beverage Changes}

Between 1977 and 2001, Americans increased the proportion of total energy obtained from soft drinks and fruit drinks, while decreasing the proportion of total energy obtained from milk. This increase from $2.8 \%$ to $7.0 \%$ of all energy for the soft drinks translates into almost a tripling of calories (from $50 \mathrm{kcal}$ to $144 \mathrm{kcal}$ ); the percent of all energy from fruit drinks increased from $1.1 \%$ to $2.2 \%$ (from $20 \mathrm{kcal}$ to $45 \mathrm{kcal}$ ). In contrast, energy intake from milk decreased from $8.0 \%$ to $5.0 \%$ for all age groups, or from $143 \mathrm{kcal}$ to $99 \mathrm{kcal}$ per person per day during the same time period. This decrease cannot be attributed to lower-fat items because both kilocalories as well as ounces decreased. Within every age group for all other beverages-including coffee and tea, alcohol, fruit drinks, and fruit juices-the changes have been minor between 1977 and 2001 (Table 1). 
Table 1. Trends in U.S. beverage consumption 1977-1996: percent of total daily calorie intake by age group and years

\begin{tabular}{|c|c|c|c|c|c|c|c|c|c|c|}
\hline Age & Years & $\begin{array}{c}\text { Coffee } \\
\text { and } \\
\text { tea }\end{array}$ & $\begin{array}{c}\text { Soft } \\
\text { drinks }\end{array}$ & $\begin{array}{l}\text { Fruit } \\
\text { drinks }\end{array}$ & $\begin{array}{c}\text { Sweetened } \\
\text { beverage }\end{array}$ & Alcohol & Milk & $\begin{array}{c}\text { Other } \\
\text { milk } \\
\text { beverage }\end{array}$ & $\begin{array}{l}\text { Fruit } \\
\text { juice }\end{array}$ & $\begin{array}{c}\text { Total } \\
\text { energy } \\
\text { (kcals) }\end{array}$ \\
\hline \multirow[t]{4}{*}{ All } & 1977-1978 & $0.8^{\mathrm{b}, \mathrm{f}}$ & $2.8^{\mathrm{a}, \mathrm{b}, \mathrm{f}}$ & $1.1^{\mathrm{b}, \mathrm{f}}$ & $3.9^{\mathrm{a}, \mathrm{b}, \mathrm{f}}$ & $1.6^{\mathrm{b}, \mathrm{f}}$ & $8.0^{a, b, f}$ & $0.5^{\mathrm{a}, \mathrm{f}}$ & $1.7^{\mathrm{a}, \mathrm{b}, \mathrm{f}}$ & $1790^{\mathrm{b}, \mathrm{f}}$ \\
\hline & 1989-1991 & 0.9 & 4.0 $0^{\mathrm{a}, \mathrm{c}, \mathrm{d}}$ & $1.2^{\mathrm{c}, \mathrm{d}}$ & $5.2^{\mathrm{a}, \mathrm{c}, \mathrm{d}}$ & $1.9^{\mathrm{c}, \mathrm{d}}$ & $6.5^{\mathrm{a}, \mathrm{c}, \mathrm{d}}$ & $0.4^{\mathrm{a}}$ & $2.0^{\mathrm{a}}$ & $1795^{\mathrm{c}, \mathrm{d}}$ \\
\hline & 1994-1996 & $0.9^{\mathrm{b}}$ & $5.2^{\mathrm{b}, \mathrm{c}, \mathrm{e}}$ & $1.9^{\mathrm{b}, \mathrm{c}, \mathrm{e}}$ & $7.1^{\mathrm{b}, \mathrm{c}, \mathrm{e}}$ & $2.3^{\mathrm{b}, \mathrm{c}, \mathrm{e}}$ & $\mathbf{5 . 0} \mathbf{0}^{\mathrm{b}, \mathrm{c}}$ & 0.4 & $2.0^{\mathrm{b}}$ & $1985^{\mathrm{b}, \mathrm{c}, \mathrm{e}}$ \\
\hline & 1999-2001 & $0.9^{f}$ & $7.0^{\mathrm{d}, \mathrm{e}, \mathrm{f}}$ & $2.2^{\mathrm{d}, \mathrm{e}, \mathrm{f}}$ & $9.2^{\mathrm{d}, \mathrm{e}, \mathrm{f}}$ & $3.5^{\mathrm{d}, \mathrm{e}, \mathrm{f}}$ & $\mathbf{5 . 0} \mathbf{d}^{\mathrm{d}, \mathrm{f}}$ & $0.3^{\mathrm{f}}$ & $2.0^{f}$ & $2068^{\mathrm{d}, \mathrm{e}, \mathrm{f}}$ \\
\hline \multirow[t]{4}{*}{$2-18$} & $1977-1978$ & 0.3 & $3.0^{\mathrm{a}, \mathrm{b}, \mathrm{f}}$ & $1.8^{\mathrm{b}, \mathrm{f}}$ & $4.8^{\mathrm{a}, \mathrm{b}, \mathrm{f}}$ & $0.1^{\mathrm{a}, \mathrm{f}}$ & $13.2^{\mathrm{a}, \mathrm{b}, \mathrm{f}}$ & $0.6^{\mathrm{b}, \mathrm{f}}$ & $1.7^{\mathrm{a}, \mathrm{b}, \mathrm{f}}$ & $1839^{\mathrm{b}, \mathrm{f}}$ \\
\hline & 1989-1991 & 0.4 & $4.0^{\mathrm{a}, \mathrm{c}, \mathrm{d}}$ & $2.1^{\mathrm{c}, \mathrm{d}}$ & $6.1^{\mathrm{a}, \mathrm{c}, \mathrm{d}}$ & $0.0^{\mathrm{a}, \mathrm{d}}$ & $11.2^{\mathrm{a}, \mathrm{c}, \mathrm{d}}$ & 0.5 & $2.5^{\mathrm{a}, \mathrm{c}}$ & $1778^{\mathrm{c}, \mathrm{d}}$ \\
\hline & 1994-1996 & 0.4 & $\mathbf{5 . 5} 5^{\mathrm{b}, \mathrm{c}, \mathrm{e}}$ & $3.1^{\mathrm{b}, \mathrm{c}}$ & $8.5^{\mathrm{b}, \mathrm{c}, \mathrm{e}}$ & $0.1^{\mathrm{e}}$ & $8.8^{\mathrm{b}, \mathrm{c}}$ & $0.4^{\mathrm{b}}$ & $2.7^{\mathrm{b}, \mathrm{c}}$ & $1958^{\mathrm{b}, \mathrm{c}}$ \\
\hline & 1999-2001 & 0.5 & $6.9^{\mathrm{d}, \mathrm{e}, \mathrm{f}}$ & $3.4^{\mathrm{d}, \mathrm{f}}$ & $10.3^{\mathrm{d}, \mathrm{e}, \mathrm{f}}$ & $0.3^{\mathrm{d}, \mathrm{e}, \mathrm{f}}$ & $8.3^{\mathrm{d}, \mathrm{f}}$ & $0.3^{\mathrm{f}}$ & $2.7^{\mathrm{f}}$ & $1917^{\mathrm{d}, \mathrm{f}}$ \\
\hline \multirow[t]{4}{*}{ 19-39 } & $1977-1978$ & $0.8^{\mathrm{b}}$ & $4.1^{\mathrm{a}, \mathrm{b}, \mathrm{f}}$ & $1.0^{\mathrm{b}, \mathrm{f}}$ & $5.1^{\mathrm{a}, \mathrm{b}, \mathrm{f}}$ & $2.6^{\mathrm{b}, \mathrm{f}}$ & $6.1^{\mathrm{a}, \mathrm{b}, \mathrm{f}}$ & $0.6^{\mathrm{a}}$ & $1.5^{\mathrm{a}, \mathrm{b}, \mathrm{f}}$ & $1855^{\mathrm{a}, \mathrm{b}, \mathrm{f}}$ \\
\hline & 1989-1991 & 0.9 & $5.3^{\mathrm{a}, \mathrm{c}, \mathrm{d}}$ & $1.1^{\mathrm{c}, \mathrm{d}}$ & $6.4^{\mathrm{a}, \mathrm{c}, \mathrm{d}}$ & $2.7^{\mathrm{c}, \mathrm{d}}$ & $\mathbf{5 . 0} 0^{\mathrm{a}, \mathrm{c}}$ & $0.3^{\mathrm{a}}$ & $1.8^{\mathrm{a}}$ & $1940^{\mathrm{a}, \mathrm{c}, \mathrm{d}}$ \\
\hline & 1994-1996 & $1.0^{\mathrm{b}}$ & $7.0^{\mathrm{b}, \mathrm{c}, \mathrm{e}}$ & $1.8^{\mathrm{b}, \mathrm{c}, \mathrm{e}}$ & $8.7^{\mathrm{b}, \mathrm{c}, \mathrm{e}}$ & $3.6^{\mathrm{b}, \mathrm{c}}$ & $3.6^{\mathrm{b}, \mathrm{c}}$ & 0.4 & $1.7^{\mathrm{b}}$ & $2198^{\mathrm{b}, \mathrm{c}, \mathrm{e}}$ \\
\hline & 1999-2001 & 1.0 & $9.8^{\mathrm{d}, \mathrm{e}, \mathrm{f}}$ & $2.5^{\mathrm{d}, \mathrm{e}, \mathrm{f}}$ & $12.3^{\mathrm{d}, \mathrm{e}, \mathrm{f}}$ & $4.8^{\mathrm{d}, \mathrm{f}}$ & $3.8^{\mathrm{f}}$ & 0.3 & $1.6^{\mathrm{f}}$ & $2321^{\mathrm{d}, \mathrm{e}, \mathrm{f}}$ \\
\hline \multirow[t]{4}{*}{$40-59$} & $1977-1978$ & 1.2 & $1.9^{\mathrm{a}, \mathrm{b}, \mathrm{f}}$ & $0.6^{\mathrm{b}, \mathrm{f}}$ & $2.5^{\mathrm{a}, \mathrm{b}, \mathrm{f}}$ & $2.4^{\mathrm{b}, \mathrm{f}}$ & $4.7^{\mathrm{a}, \mathrm{b}}$ & 0.4 & 1.7 & $1747^{\mathrm{b}}$ \\
\hline & 1989-1991 & 1.2 & $3.3^{\mathrm{a}, \mathrm{c}, \mathrm{d}}$ & $0.8^{\mathrm{c}, \mathrm{d}}$ & $4.1^{\mathrm{a}, \mathrm{c}, \mathrm{d}}$ & $2.9^{\mathrm{d}}$ & $4.1^{\mathrm{a}}$ & 0.4 & $1.5^{c}$ & $1753^{c}$ \\
\hline & 1994-1996 & 1.1 & $4.0^{\mathrm{b}, \mathrm{c}, \mathrm{e}}$ & $1.3^{\mathrm{b}, \mathrm{c}}$ & $5.3^{\mathrm{b}, \mathrm{c}, \mathrm{e}}$ & $2.9^{\mathrm{b}, \mathrm{e}}$ & $3.4^{\mathrm{b}, \mathrm{e}}$ & 0.3 & $1.6^{\mathrm{c}}$ & $1954^{\mathrm{b}, \mathrm{c}}$ \\
\hline & 1999-2001 & 1.2 & $\mathbf{5 . 0} \mathbf{0}^{\mathrm{d}, \mathrm{e}, \mathrm{f}}$ & $1.2^{\mathrm{d}, \mathrm{f}}$ & $6.2^{\mathrm{d}, \mathrm{e}, \mathrm{f}}$ & $4.9^{\mathrm{d}, \mathrm{e}, \mathrm{f}}$ & $3.9^{\mathrm{e}}$ & 0.3 & 1.6 & $2114^{\mathrm{d}, \mathrm{e}, \mathrm{f}}$ \\
\hline \multirow[t]{4}{*}{$\geq 60$} & $1977-1978$ & 1.1 & $0.9^{\mathrm{a}, \mathrm{c}, \mathrm{f}}$ & $0.6^{\mathrm{a}, \mathrm{b}, \mathrm{f}}$ & $1.5^{\mathrm{a}, \mathrm{b}, \mathrm{f}}$ & $1.4^{\mathrm{f}}$ & $5.8^{\mathrm{b}, \mathrm{f}}$ & 0.4 & $1.9^{\mathrm{a}, \mathrm{f}}$ & 1619 \\
\hline & $1989-1991$ & 1.1 & $1.6^{\mathrm{a}, \mathrm{d}}$ & $0.8^{\mathrm{a}, \mathrm{c}, \mathrm{d}}$ & $2.4^{\mathrm{a}, \mathrm{c}, \mathrm{d}}$ & $1.6^{\mathrm{d}}$ & $5.4^{\mathrm{c}}$ & 0.4 & $2.5^{\mathrm{a}}$ & 1574 \\
\hline & 1994-1996 & 1 & $1.8^{\mathrm{b}, \mathrm{e}}$ & $1.1^{\mathrm{b}, \mathrm{c}}$ & $2.9^{\mathrm{b}, \mathrm{c}, \mathrm{e}}$ & 1.9 & $4.5^{\mathrm{b}, \mathrm{c}}$ & 0.4 & 2 & 1633 \\
\hline & 1999-2001 & 1.1 & $3.0^{\mathrm{d}, \mathrm{e}, \mathrm{f}}$ & $1.2^{\mathrm{d}, \mathrm{f}}$ & $4.3^{\mathrm{d}, \mathrm{e}, \mathrm{f}}$ & $2.6^{\mathrm{d}, \mathrm{f}}$ & $4.6^{f}$ & 0.6 & $2.4^{\mathrm{f}}$ & $1710^{\mathrm{d}, \mathrm{f}}$ \\
\hline
\end{tabular}

Notes: Sweetened beverage column combines soft drinks and fruit drinks. Total energy intake encompasses mean daily intake per capita for each age grouping.

Sources: Nationwide Food Consumption Survey 1977-1978, Continuing Survey of Food Intake by Individuals (CSFII) 1989-1991, CSFII 1996, and National Health and Nutrition Examination Survey 1999-2001.

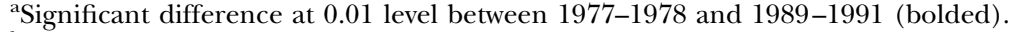

bignificant difference at 0.01 level between 1977-1978 and 1994-1996 (bolded).

'Significant difference at 0.01 level between 1989-1991 and 1994-1996 (bolded).

${ }^{\mathrm{d}}$ Significant difference at 0.01 level between 1989-1991 and 1999-2001 (bolded).

eSignificant difference at 0.01 level between 1994-96 and 1999-2001 (bolded).

fSignificant difference at 0.01 level between 1977-78 and 1999-2001 (bolded).

\section{Beverage Changes by Age}

The largest drop in milk consumption occurred in the 2- to 18-year-olds; a decrease from $13.2 \%$ of total energy in 1977 to $8.3 \%$ in 2001 . During this time period, soft drink consumption in this age group increased from $3.0 \%$ to $6.9 \%$, and fruit drink consumption increased from $1.8 \%$ to $3.4 \%$. Milk consumption played a much smaller role in total energy intake for all other age groups.

From 1977 to 2001, soft drink intake increased from $4.1 \%$ to $9.8 \%$ for 19 - to 39 -year-olds. In percentage terms, soft drink intake was highest among this age group in comparison to other ages. For 40- to 59-yearolds, soft drink intake increased from $1.9 \%$ to $5.0 \%$; for those aged $\geq 60$ years, it increased from $0.9 \%$ to $3.0 \%$. Figure 1 shows the large variation by age in the levels of intake in 2001. Young adults in particular consumed the highest levels of caloric beverages and soft drinks.

\section{Shifts in the Proportion Consuming Each Food Group, Serving, and Portion Size for Consumers}

Table 2 disaggregates the overall trends into the proportion consuming each main beverage group, the number of servings per day, and the portion size of each serving. Interestingly, the proportion consuming sweetened beverages increased by about $15 \%$, while those consuming milk declined by $12 \%$ between 1977 and 1996. During this time period, servings of sweetened beverages increased for every age group, while servings of milk decreased. For all Americans, the mean servings of sweetened beverages increased from 1.96 servings in 1977 to 2.39 servings in 1996. The mean servings of milk decreased from 2.95 servings to 2.21

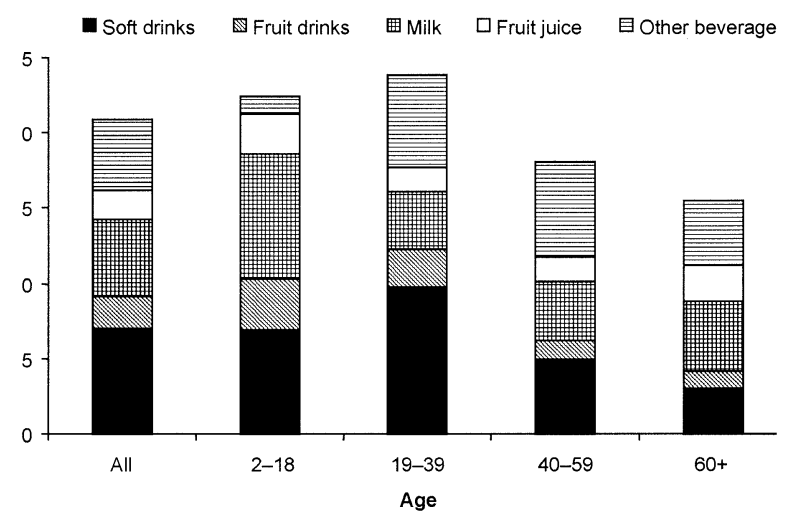

Figure 1. The percentage of calories from beverages, United States 1999-2001. (From National Health and Nutrition Examination Survey 1999-2001, weighted to be nationally representative.) 
Table 2. Trends in mean percentage of consumers, mean servings/day, and mean portions of specific beverages

\begin{tabular}{|c|c|c|c|c|c|c|c|}
\hline \multirow[b]{2}{*}{ Age } & \multirow[b]{2}{*}{ Years } & \multicolumn{3}{|c|}{ Sweetened beverages } & \multicolumn{3}{|c|}{ Milk beverages } \\
\hline & & $\%$ Consumers & Servings & Portions & $\%$ Consumers & Servings & Portions \\
\hline \multirow[t]{3}{*}{ All } & $1977-1978$ & 61.4 & 1.96 & $13.6^{\mathrm{a}, \mathrm{b}}$ & 79 & 2.95 & $11.7^{\mathrm{b}}$ \\
\hline & 1989-1991 & 69 & 2.18 & $17.2^{\mathrm{a}, \mathrm{c}}$ & 73.8 & 2.35 & 11.2 \\
\hline & $1994-1996$ & 76 & 2.39 & $21^{\mathrm{b}, \mathrm{c}}$ & 67.4 & 2.21 & $10.9^{\mathrm{b}}$ \\
\hline \multirow[t]{3}{*}{$2-18$} & 1977-1978 & 74.5 & 2.02 & $13.1^{\mathrm{a}, \mathrm{b}}$ & 94.3 & 3.46 & $15.4^{\mathrm{a}, \mathrm{b}}$ \\
\hline & 1989-1991 & 74.2 & 2.2 & $15.8^{a, c}$ & 90.3 & 2.89 & $14.1^{\mathrm{a}}$ \\
\hline & 1994-1996 & 84.7 & 2.55 & $18.9^{\mathrm{b}, \mathrm{c}}$ & 84.6 & 2.75 & $13.6^{\mathrm{b}}$ \\
\hline \multirow[t]{3}{*}{ 19-39 } & $1977-1978$ & 71.8 & 2.11 & $15.3^{\mathrm{a}, \mathrm{b}}$ & 73.2 & 2.54 & 10.7 \\
\hline & 1989-1991 & 77.8 & 2.35 & $19.9^{\mathrm{a}, \mathrm{c}}$ & 67 & 1.94 & 11.2 \\
\hline & $1994-1996$ & 83.2 & 2.6 & $25.5^{\mathrm{b}, \mathrm{c}}$ & 57.9 & 1.76 & 10.8 \\
\hline \multirow[t]{3}{*}{$40-59$} & $1977-1978$ & $49.1^{\mathrm{b}}$ & 1.69 & $12.5^{\mathrm{a}, \mathrm{b}}$ & 69.1 & 2.77 & $8.5^{\mathrm{b}}$ \\
\hline & 1989-1991 & 65.1 & 2.12 & $16.7^{\mathrm{a}, \mathrm{c}}$ & 65.7 & 2.09 & 8.8 \\
\hline & 1994-1996 & $73.5^{\mathrm{b}}$ & 2.21 & $19.8^{\mathrm{b}, \mathrm{c}}$ & 59.6 & 2.03 & $9.1^{\mathrm{b}}$ \\
\hline \multirow[t]{3}{*}{$\geq 60$} & $1977-1978$ & $30.9^{\mathrm{b}}$ & 1.52 & $10.7^{\mathrm{a}, \mathrm{b}}$ & 74.2 & 2.68 & 8.5 \\
\hline & 1989-1991 & 47.6 & 1.7 & $12.6^{\mathrm{a}, \mathrm{b}}$ & 72.7 & 2.37 & 8.6 \\
\hline & 1994-1996 & $50.8^{\mathrm{b}}$ & 1.7 & $13.6^{b, c}$ & 71.2 & 2.18 & 7.9 \\
\hline
\end{tabular}

Notes: Portions are in fluid ounces. Portions are the number of kilocalories or grams consumed by an individual at one eating occasion. Servings are the number of discrete times that individual consumes an item.

Sources: Nationwide Food Consumption Survey 1977-1978, Continuing Food Intake by Individuals (CSFII) 1989-1991, and CSFII 1996.

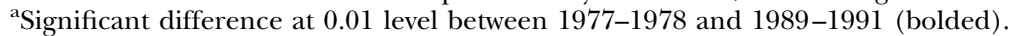

bignificant difference at 0.01 level between 1977-1978 and 1994-1996 (bolded).

'Significant difference at 0.01 level between 1989-1991 and 1994-1996 (bolded).

servings during the same time period. The largest drop in milk servings was seen for 2- to 18-year-olds: from 3.46 servings in 1977 to 2.75 servings in 1996.

Sweetened beverage portion sizes for every age group, at home as well as at fast food and restaurant locations, increased significantly over time. In contrast, there have been some very small decreases in milk portion sizes, but not nearly as dramatic as the changes (increases) seen in sweetened beverages. It is important to note that milk portion size changes were very small for all Americans and every age group (besides 2- to 18-year-olds), and most did not achieve significance.

The greatest change was seen in milk portion sizes for 2- to 18-year-olds: a decrease from $15.4 \mathrm{oz}$ in 1977 to $13.6 \mathrm{oz}$ in 1996. On the other hand, portions for sweetened beverages (all ages) increased from $13.6 \mathrm{oz}$ to $21 \mathrm{oz}$ between 1977 and 1996. This is especially important in the 19 to 39 age group, whose portions increased significantly from $15.3 \mathrm{oz}$ to $25.5 \mathrm{oz}$ during this time period. It should also be noted that the largest portions in this age group were seen at home in 1996 (21.4 oz).

\section{Location and Eating Occasion}

Sweetened beverage and milk locations, and eating occasion trends were very similar among age groups (Table 3). For all Americans, total sweetened beverages and milk, as well as those consumed as part of a meal, were consumed in the greatest percentages at home followed by restaurant/fast food locations. For each location and for every age group, sweetened beverages percentages increased and milk decreased. For both sweetened beverages and milk consumed as a snack or part of a snack, the greatest percentage were consumed at home followed by store eaten out. At the time of these surveys, vending did not play a significant role in overall beverage consumption. While the proportion of sweetened beverages has always constituted a larger percentage of snack calories than meal calories, in absolute terms there were consistently about 2.5 times as many sweetened beverage calories consumed as part of meals versus snacks for all Americans between 1977 and 1996. Milk has consistently played a much smaller role in snacks than in meals.

Between 1977 and 1996, total sweetened beverage caloric intake increased from 70 to 141 . For sweetened beverages consumed at meals, the number rose from 49 calories to 100 calories; this number doubled from 21 calories to 41 calories for snacking occasions. For total milk, the number of calories decreased from 143 calories to 99 calories during this time period. For milk consumed as part of a meal, the number dropped from 127 calories to 82 calories, while milk as a part of a snack stayed relatively constant at 17 calories.

\section{Discussion}

Increasing attention is being paid to the large increase in sweetened beverages in the United States. This trend was mainly driven by the large increase in soft drinks consumed by children (aged 2 to 18) and younger adults (aged 19 to 39). This corroborates results from many other studies showing that soft drink consumption is rising and is a significant contributor to total caloric intake for many individuals, especially children and adolescents. ${ }^{2-4,11}$ This also highlights the fact that 
Table 3. Trends in sweetened beverages and milk consumption by location, 1977-1996: percent of total energy intake by location and meal type for each time period

\begin{tabular}{|c|c|c|c|c|c|c|c|}
\hline \multirow[b]{2}{*}{ Location } & \multirow[b]{2}{*}{ Years } & \multicolumn{3}{|c|}{ All ages } & \multicolumn{3}{|c|}{ All ages } \\
\hline & & $\begin{array}{c}\text { Total } \\
\text { sweetened } \\
\text { beverage }\end{array}$ & $\begin{array}{c}\text { Meal } \\
\text { sweetened } \\
\text { beverage }\end{array}$ & $\begin{array}{c}\text { Snack } \\
\text { sweetened } \\
\text { beverage }\end{array}$ & $\begin{array}{c}\text { Total } \\
\text { milk }\end{array}$ & $\begin{array}{l}\text { Meal } \\
\text { milk }\end{array}$ & $\begin{array}{r}\text { Snack } \\
\text { milk }\end{array}$ \\
\hline \multirow[t]{3}{*}{ Vending } & $1977-1978$ & $0.2^{\mathrm{b}}$ & $0.1^{\mathrm{a}, \mathrm{b}}$ & $0.9^{\mathrm{b}}$ & $0.1^{\mathrm{a}, \mathrm{b}}$ & $0.0^{\mathrm{a}, \mathrm{b}}$ & $0.1^{a, b}$ \\
\hline & $1989-1991$ & $0.2^{\mathrm{c}}$ & $0.1^{\mathrm{a}, \mathrm{c}}$ & $0.8^{c}$ & $0.0^{\mathrm{a}}$ & $0.0^{\mathrm{a}}$ & $0.0^{\mathrm{a}}$ \\
\hline & 1994-1996 & $0.3^{\mathrm{b}, \mathrm{c}}$ & $0.2^{\mathrm{b}, \mathrm{c}}$ & $1.0^{\mathrm{b}, \mathrm{c}}$ & $0.0^{\mathrm{b}}$ & $0.0^{\mathrm{b}}$ & $0.0^{\mathrm{b}}$ \\
\hline \multirow[t]{3}{*}{ Ate at home } & $1977-1978$ & $2.6^{\mathrm{a}, \mathrm{b}}$ & $2.0^{\mathrm{a}, \mathrm{b}}$ & $6.8^{\mathrm{a}, \mathrm{b}}$ & $6.5^{\mathrm{a}, \mathrm{b}}$ & $6.3^{\mathrm{a}, \mathrm{b}}$ & 7.5 \\
\hline & 1989-1991 & $3.3^{a, c}$ & $2.7^{\mathrm{a}, \mathrm{c}}$ & $7.3^{\mathrm{a}, \mathrm{c}}$ & $5.5^{\mathrm{a}, \mathrm{c}}$ & $5.4^{a, c}$ & 5.7 \\
\hline & $1994-1996$ & $3.9^{\mathrm{b}, \mathrm{c}}$ & $3.3^{\mathrm{b}, \mathrm{c}}$ & $6.8^{\mathrm{b}, \mathrm{c}}$ & $4.1^{b, c}$ & $4.1^{\mathrm{b}, \mathrm{c}}$ & 4.3 \\
\hline \multirow{3}{*}{ Store eaten out } & $1977-1978$ & $0.3^{\mathrm{b}}$ & $0.2^{\mathrm{a}, \mathrm{b}}$ & $1.0^{\mathrm{b}}$ & $0.3^{\mathrm{a}, \mathrm{b}}$ & $0.3^{\mathrm{a}, \mathrm{b}}$ & $0.3^{\mathrm{a}}$ \\
\hline & 1989-1991 & $0.3^{c}$ & $0.2^{\mathrm{a}, \mathrm{c}}$ & $1.3^{\mathrm{c}}$ & $0.1^{\mathrm{a}, \mathrm{c}}$ & $0.1^{\mathrm{a}, \mathrm{c}}$ & $0.1^{\mathrm{a}, \mathrm{c}}$ \\
\hline & $1994-1996$ & $0.7^{\mathrm{b}, \mathrm{c}}$ & $0.4^{\mathrm{b}, \mathrm{c}}$ & $1.8^{\mathrm{b}, \mathrm{c}}$ & $0.1^{b, c}$ & $0.1^{\mathrm{b}, \mathrm{c}}$ & $0.2^{\mathrm{c}}$ \\
\hline \multirow[t]{3}{*}{ Restaurant/fast food } & $1977-1978$ & $0.6^{\mathrm{a}, \mathrm{b}}$ & $0.6^{\mathrm{a}, \mathrm{b}}$ & $1.0^{\mathrm{b}}$ & $0.3^{\mathrm{b}}$ & $0.3^{\mathrm{b}}$ & $0.3^{\mathrm{b}}$ \\
\hline & $1989-1991$ & $1.2^{a, c}$ & $1.2^{a, c}$ & $1.1^{\mathrm{c}}$ & $0.3^{c}$ & $0.3^{c}$ & 0.1 \\
\hline & 1994-1996 & $1.7^{\mathrm{b}, \mathrm{c}}$ & $1.8^{\mathrm{b}, \mathrm{c}}$ & $1.2^{\mathrm{b}, \mathrm{c}}$ & $0.1^{\mathrm{b}, \mathrm{c}}$ & $0.1^{\mathrm{b}, \mathrm{c}}$ & $0.1^{\mathrm{b}}$ \\
\hline \multirow[t]{3}{*}{ All locations } & $1977-1978$ & $3.9^{\mathrm{a}, \mathrm{b}}$ & $3.1^{\mathrm{a}, \mathrm{b}}$ & $10.3^{\mathrm{a}, \mathrm{b}}$ & $\mathbf{8 . 0}^{\mathrm{a}, \mathrm{b}}$ & $8.0^{\mathrm{a}, \mathrm{b}}$ & $8.6^{\mathrm{a}}$ \\
\hline & 1989-1991 & $5.2^{a, c}$ & $4.3^{\mathrm{a}, \mathrm{c}}$ & $11.3^{a, c}$ & $6.5^{\mathrm{a}, \mathrm{c}}$ & $6.5^{\mathrm{a}, \mathrm{c}}$ & $6.2^{a, c}$ \\
\hline & $1994-1996$ & $7.1^{\mathrm{b}, \mathrm{c}}$ & $6.1^{b, c}$ & $11.6^{\mathrm{b}, \mathrm{c}}$ & $5.0^{b, c}$ & $5.0^{\mathrm{b}, \mathrm{c}}$ & $4.9^{c}$ \\
\hline
\end{tabular}

Notes: Total sweetened beverage column combines soft drinks and fruit drinks.

Sources: Nationwide Food Consumption Survey 1977-1978, Continuing Survey of Food Intake by Individuals (CSFII) 1989-1991, and CSFII 1996.

${ }^{\text {a}}$ Significant difference at the 0.01 level between 1977-1978 and 1989-1991 (bolded).

'bignificant difference at the 0.01 level between 1977-1978 and 1994-1996 (bolded).

'Significant difference at the 0.01 level between 1989-1991 and 1994-1996 (bolded).

much of caloric sweetener consumption in the United States is from soft drinks. ${ }^{5}$

This paper explores these trends. Three components of dietary change for the soft drink and fruit drink sweetened beverage category among consumers are (1) the proportion of persons of all ages consuming these beverages has increased, (2) the portion sizes have increased, and (3) the number of servings has increased. The decrease in milk consumption can be mostly attributed to decreased proportions of those consuming milk and to a reduced number of servings. Milk portions have not changed greatly.

One critical public health dimension that most likely has been affected by these opposite trends is the reduction in milk intake. This is a new area with interesting findings that seems to point to a role for milk as a component of the diet linked with reduced weight. There are studies, both clinical and epidemiologic, that show dairy products may have a favorable effect on weight. ${ }^{17-21}$ Milk has nutritive value, containing protein as well as calcium, and is fortified with vitamin $D$. Milk is a major source of calcium, and child and adolescent calcium intake has been decreasing ${ }^{10}$ in the United States. However, there is no calcium biomarker to verify these trends.

The obesity epidemic may be aggravated by the increase in sweetened beverage intake. ${ }^{6}$ The issue of caloric sweetener and its potential effects on obesity and other metabolic disorders is not yet either fully understood or accepted. A longitudinal study by Ludwig et $\mathrm{al}^{2}$ showed the effect of increased consumption of sugar-sweetened beverages on increased energy intake and obesity among U.S. teens. A more highly controlled clinical study conducted in Denmark ${ }^{22}$ showed similar results, mainly that sweetened beverage intake was associated with considerable weight gain.

Another issue that needs to be further examined is the fact that most soft drinks were made with sucrose in the 1970s, while in the 1990s and currently they are made with high-fructose corn syrup. As yet it is unclear how much of a role this has played in the obesity epidemic, but it may be a cause for concern. ${ }^{23}$

Some potential limitations of the study are that the methods for collecting dietary data changed over time, ${ }^{24,25}$ and that persons who were overweight most likely under-reported their energy intake. ${ }^{24-28}$ The extent of this underreporting has increased over time. ${ }^{29}$ Due to increases in under-reporting, it is likely that the current estimates of beverages were underestimated and that beverages played a larger role in Americans' diets.

Little research has focused on the beneficial impacts of reduced soft drink and fruit drink intake. This would seem to be one of the simpler ways to reduce obesity in the United States.

We are grateful to Dan Blanchette for programming assistance and Frances Dancy for support in administrative matters. Financial support for this study was provided by the National Dairy Council and the National Institutes of Health (R01-HD39183-01 and R01 HD041375). 


\section{References}

1. Nielsen SJ, Siega-Riz AM, Popkin BM. Trends in energy intake in U.S. between 1977 and 1996: Similar shifts seen across age groups. Obes Res 2002;10:370-8

2. Ludwig DS, Peterson KE, Gortmaker SL. Relation between consumption of sugar-sweetened drinks and childhood obesity: a prospective, observational analysis. Lancet 2001;357:505-8.

3. Guthrie JF, Morton JF. Food sources of added sweeteners in the diets of Americans. J Am Diet Assoc 2000;100:43-51.

4. Harnack L, Stang J, Story M. Soft drink consumption among US children and adolescents: nutritional consequences. J Am Diet Assoc 1999;99:436-41.

5. Popkin, BM, Nielsen SJ. The sweetening of the world's diet. Obes Res 2003;11:1325-32.

6. Bray GA, Nielsen SJ, Popkin BM. Consumption of high-fructose corn syrup in beverages may play a role in the epidemic of obesity. Am J Clin Nutr 2004;79:537-43.

7. Lin B, Frazao E, Guthrie J. Contribution of away from home foods to American diet quality. Fam Econ Nutr Rev 1999;12:85-9.

8. Nielsen SJ, Popkin BM. Patterns and trends in food portion sizes, 19771998. JAMA 2003;289:450-3.

9. Nielsen SJ, Siega-Riz AM, Popkin BM. Trends in food locations and sources among adolescents and young adults. Prev Med 2002;35:107-13.

10. Cavadini C, Siega-Riz AM, Popkin BM. US adolescents' food intake trends from 1965-1996. Arch Dis Childhood 2000;83:18-24.

11. French SA, Lin BH, Guthrie JF. National trends in soft drink consumption among children and adolescents age 6 to 17 years: prevalence, amounts, and sources, 1977/1978 to 1994/1998. J Am Diet Assoc 2003;103:1326-31.

12. Guthrie JF, Morton JF. Food sources of added sweeteners in the diets of Americans. J Am Diet Assoc 2000;100:43-51.

\section{What This Study Adds}

This study uses nationally representative data to quantify the 24-year changes in American's beverage consumption patterns; specifically the increases in sweetened beverages and decreases in milk.

This study highlights the fact that Americans in 2001 are consuming more energy from sugared beverages in larger portions and more servings per day than in 1977.
13. Tippett KS, Mickle SJ, Goldman JD, Sykes KE, Cook DA, Sebastian RS. Food and nutrient intakes by individuals in the United States, 1 day, 1989-91. Continuing survey of food intakes by individuals 1989-91. Nationwide Food Surveys Rep 91-2. Washington DC: U.S. Department of Agriculture, Agriculture Research Service, 1995.

14. Tippett KS, Cypel YS. Design and operation: the continuing survey of food intakes by individuals and the diet and health knowledge survey 1994-96. Continuing survey of food intakes by individuals 1994-96. Nationwide Food Surveys Rep 96-1. Washington DC: U.S. Department of Agriculture, Agriculture Research Service, 1998.

15. Rizek RL. The 1977-78 Nationwide Food Consumption Survey. Fam Econ Rev 1978;4:3-7.

16. National Center for Health Statistics. National Health and Nutrition Examination Survey. Hyattsville MD: U.S. Department of Health and Human Services, National Center for Health Statistics, 2003. Available at: www.cdc.gov/nchs/nhanes.htm. Accessed January, 2004.

17. Carruth, BR, Skinner JD. The role of dietary calcium and other nutrients in moderating body fat in preschool children. Int J Obes Relat Metab Disord 2001;25:559-66.

18. Davies KM, Heaney RP, Recker RR et al. Calcium intake and body weight. J Clin Endocrinol Metab 2000;85:4635-8.

19. Pereira MA, Jacobs Jr, DR Van Horn L, et al. Dairy consumption, obesity, and the insulin resistance syndrome in young adults: the CARDIA Study. JAMA 2002;287:2081-9.

20. Zemel MB, Shi H, Greer B, Dirienzo D, Zemel PC. Regulation of adiposity by dietary calcium. FASEB J 2000;14:1132-8.

21. Barr SI, McCarron DA, Heaney RP, et al. Effects of increased consumption of fluid milk on energy and nutrient intake, body weight, and cardiovascular risk factors in healthy older adults. J Am Diet Assoc 2000;100:810-7.

22. Raben A, Vasilaras TH, Moller AC, Astrup A. Sucrose compared with artificial sweeteners: different effects on ad libitum food intake and body weight after $10 \mathrm{wk}$ of supplementation in overweight subjects. Am J Clin Nutr 2002;76:721-9.

23. Bray GA, Nielsen SJ, Popkin BM. Consumption of high-fructose corn syrup in beverages may play a role in the epidemic of obesity. Am J Clin Nutr 2004;79:537-43.

24. Bandini LG, Schoeller DA, Cyr HN, Dietz WH. Validity of reported energy intake in obese and nonobese adolescents. Am J Clin Nutr 1990;52:421-5.

25. Bjorntorp P, Bergman H, Varnauskas E, Lindholm B. Lipid mobilization in relation to body composition in man. Metabolism 1969;18:840-51.

26. Brown PJ, Konner M. An anthropological perspective on obesity. Ann N Y Acad Sci 1987;499:29-46.

27. Romieu I, Willett WC, Stampfer MJ, et al. Energy intake and other determinants of relative weight. Am J Clin Nutr 1988;47:406-12.

28. Schoeller DA. Limitations in the assessment of dietary energy intake by self-report. Metabolism 1995;44(suppl 2):18-22.

29. Heitmann BL, Lissner L, Osler M. Do we eat less fat, or just report so? Int J Obes Relat Metab Disord 2000;24:435-42. 